\title{
Examination of Occupational Anxiety Levels and Academic Self-efficacy of Physical Education Teacher Candidates
}

\author{
Zeka Pehlevan*, Eda Muştu, Fatma Çepikkurt \\ Physical Education and Sport High School, Mersin University, Turkey
}

Copyright $(2017$ by authors, all rights reserved. Authors agree that this article remains permanently open access under the terms of the Creative Commons Attribution License 4.0 International License

\begin{abstract}
This study aims at determining the occupational anxiety level of pre-service physical education teachers according to variables, and revealing the correlation between occupational anxiety and academic self-efficacy. Study group consists of 586 pre-service teachers from 10 different universities in Turkey. Data is collected by "Occupational Anxiety Scale for Pre-Service Teachers $(O A S)$ " and "Academic Self-Efficacy Scale (ASES)". T-test and One-Way ANOVA are used for data analysis, and Levene test is conducted for variance equality. Confidence interval is .95 . For gender variables, the results reveal that women's occupational anxiety is significantly higher than men's in the dimensions of OAS "total occupational anxiety", "socio-economic anxiety" and "school management anxiety" $(p<.05)$. According to grade levels, there is significant differentiation in the dimension of OAS "total occupational anxiety", "job-oriented anxiety", "socio-economic anxiety", "interaction with students' anxiety", "colleagues and students' parents anxiety" $(p<.05)$. For variables of participation in socio-cultural and sportive activities and in "socio-economic" dimension, the participants, who never participate in any activities, have significantly higher level of occupational anxiety than those who regularly participate in activities $(\mathrm{p}<.05)$. There is also a negative correlation between OAS and ASES $(\mathrm{p}<.01)$.
\end{abstract}

Keywords Pre-service, Physical Education Teacher, Occupational Anxiety, Academic Self-efficacy

\section{Introduction}

\subsection{Occupational Anxiety}

In philosophical thought, the concept of "anxiety" means that an individual does not consider him/herself worthy of existing before God [1], yet in psychological sciences, anxiety means a dominant psychological state of worry, nervousness or unease about a fear or something bad to happen [2]. Anxiety is also defined as emotional state of uneasiness, uncertainty, fear, concern, distress and loss of control felt by a person facing a threatening situation [3] and as an uncertain fear with no object [4]. Having conflict between one's motives to meet the basic needs may lead to develop anxiety and frustration feelings [5]. In order to mitigate anxiety and cope with conflicts, a person can develop certain behaviors such as forgetting, distorting motives, accusing others, making up excuses, taking out on somebody, developing fantasy, identification, puerility and sublimation [4]. The severity of anxiety can vary from a slight mood of unease and discomfort to a severe level of panic, and occurs in any situation that threatens the integrity of the personality. If the strategies used by a person to cope with anxiety are not effective, anxiety can cause psychoneurosis disorders [1].

Fuller [6] identifies three groups of teaching profession anxiety: egocentric anxiety, job-oriented anxiety and student-oriented anxiety. Teacher candidates are in the center of egocentric anxiety, questioning whether teaching is an appropriate profession for them. While job-oriented anxiety represents the anxiety of a teacher candidate about whether s/he can successfully carry on the education period, student-oriented anxiety reflects the anxieties of a teacher candidate about whether s/he can successfully plan a lasting teaching activity that responds to the needs and expectations of his/her students [7-10]. The anxieties of novice physical education teachers are examined under the categories of teacher's self-concerns, students, classroom management, procedures and safety; and it is indicated that as a result of an increase in the number of students in the classroom of the novice teachers, they started to experience an uneasiness about having a difficulty in teaching-learning process, a concern about giving poor education, and they felt anxious about their occupational inability and personal development. The occupational anxieties of teacher candidates focus on 
certain points within a certain period of time [9]. In particular, these anxieties peak up when it is time for the Public Personnel Selection Examination (KPSS), which is centrally organized by the government so that teacher candidates can be appointed to the profession [11, 12].

Additionally, the studies showed that teacher candidates had economic and social anxieties and concerns about effective communication, adaptation to school and school environment, being neglected, lacking support and getting along with school management $[10,13]$. It was observed that the novice physical education teachers had more safety concerns related to possible fractures (arm, leg, finger and nose), bleedings, bruises and contusions in physical education classes; it was also reported that the candidates were concerned about how to follow a procedure, the lack of equipment and materials, weather conditions, students' locker room activities and theft [10]. The studies on the future of teaching profession revealed that teacher candidates expressed their concerns about the uncertain and unstable future of the profession due to unqualified teachers, appointment and employment, crowded classrooms, failure to succeed in profession, lack of school equipment, negligence towards physical education lessons, inadequate teaching hours, the lack of career opportunities and insufficient salary and benefits [12, 14]. Occupational anxiety is also one of the reasons why teachers leave their jobs. Gray and Taie reported in a longitudinal study (conducted between 2007-2012) that 17\% of teachers quit within the first 5 years.

It was observed that the previous studies on the occupational anxieties of teacher candidates targeted form teachers as well as science, math, physical education and pedagogical formation teachers as well as teachers for the mentally handicapped; and these studies focused on the impact of independent variables such as gender, employment, class level, academic success, parental attitude, economic situation, type of high school and being a licensed athlete and on the dependent variables such as occupational anxiety, occupational attitudes, self-efficacy and academic self-efficacy [16-22].

Anxiety can also influence the academic performance of the learner. According to the Yerkes-Dodson Law, low and moderate level of anxiety can cause positive performance while high level of anxiety can be destructive. Therefore, severe anxiety can result in negative motivation and ultimate failure of a teacher candidate to perform his/her task. In this context, the level of anxiety can affect one's belief in his/her ability to succeed [23]. According to Spielberger (2016), individuals with lower level of anxiety are more successful than those with higher level of anxiety [2]. There is a considerably negative correlation between the perception of occupational self-efficacy and anxiety [9]. For this reason; low anxiety -thanks to its stimulant, protective and motivational features - stimulates the individual against the undesired situations and motivates them to stand up to possible failures [22].

\subsection{Self-Efficacy and Academic Self-Efficacy}

In the light of this information, it is possible to suggest that one of the factors elevating the anxiety level is how an individual perceives and believes in his/her self-efficacy. The reason why people are interested in the perception of self-efficacy in education process is due to its impact on motivation [23] as one's motivation and perception of self-efficacy has a strong influence on his/her success [24]. Self-efficacy is defined as the belief in the ability of a person to perform specific actions to achieve desired outcomes [24]; one's self judgment of his/her own capacity to successfully organize and implement the required activities for achieving a certain level of performance; one's self judgment and belief in how s/he can successfully overcome possible challenges in the future [25]. In other words, self-efficacy is the individuals' self-perception about their capability and capacity to cope with different situations and succeed in performing certain activities [26]. The judgments of self-efficacy are influenced by individuals' direct and indirect experiences, verbal persuasions such as encouragement, advice, and suggestions by other people and their psychological states [26].

Self-efficacy describes one's beliefs in his/her own capabilities to shape his/her life in order to work and exert effort [23]. Self-efficacy is also effective in increasing success. Individuals with low level of self-efficacy can easily fall into despair and give up whereas the ones with higher level of self-efficacy can achieve higher goals and increase their possibility to be successful [24]. Success and achievement increase the belief of efficacy yet failures show a reverse effect. Individuals with a high level of self-efficacy perception tend to improve their perceptions about their own abilities and consider the challenges they face related to the responsibilities to be achieved, thus they are more determined, more successful and less stressful [27]. On the other hand, individuals with low level of self-efficacy tend to complain about their efficacy whenever they experience any challenge [25].

One of the concepts of "self-efficacy" is academic self-efficacy. Academic self-efficacy is defined as one's self-competency and self-belief in his/her successful accomplishment of education goals and academic tasks assigned to him/her during an education period [27-33]. In an academic learning environment, students may differ in their beliefs about how skillful they are in acquiring new skills and knowledge, and managing materials. The initial belief of self-efficacy can change as a function of previous experiences and aptitudes. While students are working, their academic self-efficacy is affected by awards, teacher feedbacks and certain personal factors such as their goals and information processing [34]. When students have a perception of a good progression in learning, they work on their tasks and improve their skills; their motivation increases and they acquire a sense of self-sufficiency to have a better performance [27]. Students, lacking academic self-efficacy, exaggerate the potential challenges they face 
and thus believe that they are inadequate to overcome [25, 35]. Students with academic self-efficacy show tendency to minimize the potential challenges they face while fulfilling their duty, put more effort to complete their tasks and carefully focus [23] so that they can have better stress management [29].

While giving training to pre-service teachers, it is desired that a PE teacher is competent in his/her profession and has a sense of self-sufficiency. PE teacher is also expected to successfully perform syllabus and lesson plan [36] since the quality and self-efficacy of a teacher [37] have an influence on his/her teaching program and success in teaching, thus it may lead to change student behaviors [38]. What is expected from the teachers is that they can achieve these skills successfully, which is closely related to the quality of pre-service training they have and their perception of occupational self-efficacy $[39,40]$.

The study conducted on the perception of academic self-efficacy revealed that the perception of academic self-efficacy did not vary by gender [41, 43], yet for university students it differed in favor of men [44]; the perception of academic self-efficacy significantly differed according to class level - the higher the class level was, the higher was the score of academic self-efficacy [45-47] - and there was a positive correlation between academic self-efficacy and success $[41,47,48]$. The study conducted with the university students in Romania by Catalina et. al [49] found out that there was a positive correlation between emotional intelligence and academic self-efficacy, and predicted that emotional intelligence affected the academic self-efficacy by $25.7 \%$ while academic self-efficacy affected the academic success by $47.4 \%$. Other studies reported that the academic self-efficacy perceptions of teacher candidates significantly predicted test anxiety, tendency to academic fraud, the focus of academic control, academic success and academic motivation $[42,44]$.

In consideration of these explanations, it is possible to keep the anxieties of teacher candidates under control and increase their academic self-efficacy through pre-service training. Therefore, the analysis of the occupational anxiety levels and academic self-efficacy perceptions of physical education teacher candidates can provide an opportunity to understand, explain, solve and improve their attitudes. Additionally, the outcome of this study can also contribute to improve teachers' training programs, intensify their efforts in education process, improve their skills to overcome challenges and increase their academic motivation and success.

The main objective of this study is to determine the occupational anxiety level and academic self-efficacy of the physical education teacher candidates, and to examine the correlation between these two variables. To this end, the main research questions are identified as below:

1. What is the occupational anxiety and academic self-efficacy level of the participants?
2. Are the occupational anxiety and academic self-efficacy levels of the participants varied by gender, class level, participation in social activities and the variables of the evaluation of subjective academic achievement?

3. Is there a correlation between the occupational anxiety levels and academic self-efficacy perceptions of the participants?

\section{Materials and Methods}

\subsection{Model}

This is a descriptive and cross-sectional study. The independent variables of the study are gender, class, participation in social activities and academic success. The dependent variables of the study are occupational anxiety and academic self-efficacy.

\subsection{Study Group}

The study group consists of total 586 teacher candidates who are $1^{\text {st }}$ to $4^{\text {th }}$ grade students of physical education departments of 10 different universities (Aksaray, Anadolu, Cumhuriyet, Çukurova, Fırat, İnönü, Kafkas, Kocaeli, Mersin and Pamukkale) in Turkey. $56.8 \%$ of the participants is male and $43.2 \%$ is female. The mean age of the participants is 21.40 and $\mathrm{SD}=2.40$. Demographic characteristics of the participants are given in Table 1.

Table 1. Demographic characteristics of the sample group

\begin{tabular}{|c|c|c|c|}
\hline Variables & Groups & $\mathrm{f}$ & $\%$ \\
\hline \multirow{2}{*}{ Gender } & Male & 333 & 56.8 \\
\hline & Female & 253 & 43.2 \\
\hline \multirow{10}{*}{ University } & Mersin & 74 & 12.6 \\
\hline & Cumhuriyet & 60 & 10.2 \\
\hline & Anadolu & 37 & 6.3 \\
\hline & Kafkas & 72 & 12.3 \\
\hline & Firat & 70 & 11.9 \\
\hline & Aksaray & 72 & 12.3 \\
\hline & Kocaeli & 58 & 9.9 \\
\hline & Cukurova & 62 & 10.6 \\
\hline & Pamukkale & 39 & 6.7 \\
\hline & Inönü & 42 & 7.2 \\
\hline \multirow{4}{*}{ Grade level } & $1^{\text {st }}$ & 162 & 27.6 \\
\hline & $2^{\text {nd }}$ & 146 & 24.9 \\
\hline & $3^{\text {rd }}$ & 145 & 24.7 \\
\hline & $4^{\text {th }}$ & 133 & 22.7 \\
\hline \multirow{3}{*}{$\begin{array}{c}\text { Participation in social } \\
\text { activities }\end{array}$} & Yes & 321 & 54.8 \\
\hline & Sometimes & 210 & 35.8 \\
\hline & No & 55 & 9.4 \\
\hline \multirow{3}{*}{$\begin{array}{l}\text { Evaluation of subjective } \\
\text { academic achievement }\end{array}$} & Poor & 33 & 5.6 \\
\hline & Middle & 323 & 55.1 \\
\hline & Good & 230 & 39.2 \\
\hline
\end{tabular}




\subsection{Data Collection Tools}

Occupational Anxiety Scale for Pre-Service Teachers $(O A S)$ was developed as a five point Likert scale by Cabi and Yalçınalp [13] with the participation of $1^{\text {st }}-4^{\text {th }}$ grade pre-service teachers in the faculty of education $(n=283)$. The content validity of the scale was confirmed by the experts' opinion. Construct validity was examined by factor structure and it consisted of 45 items and 8 sub-factors, namely job-oriented anxiety, socio-economic anxiety, interaction with student anxiety, colleagues and students' parents anxiety, individual self-development anxiety, occupational exam anxiety, adaptation anxiety and school management. These factors corresponded to $65.7 \%$ of the total variance. Cronbach alpha coefficients of eight factors in the scale ranged from .67 to .94 . The study revealed that the factors corresponded to $62.5 \%$ of the total variance, and total Cronbach alpha value was .96. The mean scores of the scale were considered as "low", "middle" and "high" when the occupational anxiety level was between $1-2.33 ; 2.34-3.67$; and $3.68-5.00$, respectively.

Academic Self-Efficacy Scale (ASES) was developed by Owen and Froman [50] to help students determine their self-confidence in activities such as taking notes, responding to questions, writing, adapting to class and using computers. The original scale consisted of three dimensions (social status, cognitive applications and technical skills) and had totally 33 items. The test re-test internal consistency reliability mean co-efficient of the five-point Likert scale was calculated as .85 . The adaptation of the scale to Turkish context was done by Ekici [33] with the participation of 683 university students. Explanatory Factor Analysis (EFA) was applied for construct validity of the scale and it was stated that the scale consisted of three factors, corresponded to $45.8 \%$ of the total variance and overlapped with 33 items on the original scale. Cronbach alpha values in the reliability analysis for each dimension were found as .88 for "social status" dimension, .82 for "cognitive applications" dimension, and .90 for "technical skill" dimension. For this study, it was found that the total variance explained by the factors was $42.3 \%$ and Cronbach alpha value was .93.The mean scores of the scale were classified as "low", "middle" and "high" while the academic self-efficacy level was between $1-2.33 ; 2.34-3.67$; and $3.68-5.00$, respectively.

\subsection{Process}

The universities, where we collected data, were determined according to geographical regions. Permissions were obtained from the administrators of physical education teaching departments of 10 different universities. An application guideline, scale forms and return envelops with address information were sent to the departments that approved the permission. Guideline desires a voluntary participation. Totally 750 scale forms were delivered, however 607 were returned. Thus the rate of return is $81.1 \%$. A normality test was conducted before the data analysis and 21 participants affecting the normal distribution were deleted from the dataset.

\subsection{Analysis of Data}

In the analysis of data, $t$ test was used for independent groups, One Way Variance Analysis (ANOVA) for more than two groups, and Welch test of Robus tests for more than two groups with non-normal distribution. Tukey was used as Post Hoc test for normal distribution, and Tamhane's T2 test for the situations with non-normal distribution. Pearson Product-Moment Correlation technique was used to determine the relation between the variables. The confidence interval was .95 .

\section{Results}

Table 2 shows that the participants have the highest level of anxiety at "Occupational exam anxiety" sub-scale and the lowest level of anxiety at "Job-oriented anxiety" sub-scale. In Academic Self-Efficacy Scale, the participants have the highest level of efficacy at "Cognitive Applications" sub-scale and the lowest level of efficacy at "Technical Skills" sub-scale.

Table 2. Mean, standard deviation, kurtosis and skewness scores of the Vocational Anxiety and Academic Self-Efficacy Scale scores

\begin{tabular}{|l|c|c|c|c|c|c|c|}
\hline Scales and Subscales & $\mathrm{N}$ & Min & Max & Mean & SD & Skewness & Kurtosis \\
\hline Vocational Anxiety Scale (total) & 586 & 1.00 & 4.18 & 1.90 & .60 & .83 & .34 \\
\hline Job oriented anxiety & 586 & 1.00 & 3.93 & 1.62 & .63 & 1.24 & 1.07 \\
\hline Socio-economic anxiety & 586 & 1.00 & 5.00 & 2.42 & .93 & .33 & -.50 \\
\hline Interaction with student anxiety & 586 & 1.00 & 4.67 & 1.68 & .71 & 1.20 & 1.07 \\
\hline Colleagues and students' parents anxiety & 586 & 1.00 & 4.80 & 1.62 & .68 & 1.37 & 1.82 \\
\hline Individual self-development anxiety & 586 & 1.00 & 5.00 & 1.75 & .88 & 1.31 & 1.09 \\
\hline Occupational exam anxiety & 586 & 1.00 & 5.00 & 2.72 & 1.11 & .26 & -.69 \\
\hline Adaptation anxiety & 586 & 1.00 & 5.00 & 1.92 & .87 & .90 & .35 \\
\hline School management anxiety & 586 & 1.00 & 5.00 & 2.21 & .89 & .51 & -.31 \\
\hline Academic Self-Efficacy Scale (Total) & 586 & 1.21 & 5.00 & 3.45 & .63 & -.14 & .09 \\
\hline Social status & 586 & 1.20 & 5.00 & 3.37 & .68 & -.08 & -.04 \\
\hline Cognitive applications & 586 & 1.21 & 5.00 & 3.51 & .67 & -.20 & -.03 \\
\hline Technical skills & 586 & 1.25 & 5.00 & 3.32 & .83 & -.01 & -.53 \\
\hline
\end{tabular}


The results of Levene test in Table 3 show that the variances are equal in the total and sub-scales of Occupational Anxiety Scale and Academic Self-Efficacy Scale. There is a significant difference in the total scores of Occupational Anxiety Scale by gender $\left[t_{(584)}=2.021, p=.044\right]$. The comparison between the groups shows that females' anxiety levels in "economic/social" and "occupational exam anxiety" sub-scales are significantly higher than males' anxiety level in total scores of Occupational Anxiety Scale $(p<.05)$. There is also a significant difference in total scores of Academic Self-Efficacy Scale in terms of gender $[F(584)=2.233 ; p=.026]$. It also reveals that females have significantly higher scores in Academic Self-Efficacy Scale and "cognitive application efficacy" sub-dimensions than males $(p<.05)$.

Table 3. Mean, standard deviation, and t test results of Vocational Anxiety and Academic Self-Efficacy Scale scores according to gender

\begin{tabular}{|c|c|c|c|c|c|c|c|}
\hline Scale and Subscales & Gender & $\mathrm{N}$ & Mean & $\mathrm{SD}$ & df & $\mathrm{t}$ & $\mathrm{p}$ \\
\hline \multirow{2}{*}{ Vocational Anxiety Scale (Total) } & Male & 333 & 1.85 & .60 & \multirow{2}{*}{584} & \multirow{2}{*}{$-2.021 *$} & \multirow{2}{*}{.044} \\
\hline & Female & 253 & 1.95 & .58 & & & \\
\hline \multirow{2}{*}{ Job oriented anxiety } & Male & 333 & 1.61 & .63 & \multirow{2}{*}{584} & \multirow{2}{*}{-.834} & \multirow{2}{*}{.405} \\
\hline & Female & 253 & 1.65 & .64 & & & \\
\hline \multirow{2}{*}{ Socio-economic anxiety } & Male & 333 & 2.33 & .91 & \multirow{2}{*}{584} & \multirow{2}{*}{$-2.623 *$} & \multirow{2}{*}{.009} \\
\hline & Female & 253 & 2.53 & .96 & & & \\
\hline \multirow{2}{*}{ Interaction with students anxiety } & Male & 333 & 1.64 & .71 & \multirow{2}{*}{584} & \multirow{2}{*}{-1.581} & \multirow{2}{*}{.114} \\
\hline & Female & 253 & 1.74 & .72 & & & \\
\hline \multirow{2}{*}{ Colleagues and students' parents anxiety } & Male & 333 & 1.59 & .70 & \multirow{2}{*}{584} & \multirow{2}{*}{-1.038} & \multirow{2}{*}{.299} \\
\hline & Female & 253 & 1.65 & .65 & & & \\
\hline \multirow{2}{*}{ Individual self-development anxiety } & Male & 333 & 1.74 & .90 & \multirow{2}{*}{584} & \multirow{2}{*}{-.207} & \multirow{2}{*}{.836} \\
\hline & Female & 253 & 1.75 & .85 & & & \\
\hline \multirow{2}{*}{ Occupational exam anxiety } & Male & 333 & 2.54 & 1.05 & \multirow{2}{*}{584} & \multirow{2}{*}{$-4.502 *$} & \multirow{2}{*}{.000} \\
\hline & Female & 253 & 2.95 & 1.15 & & & \\
\hline \multirow{2}{*}{ Adaptation anxiety } & Male & 333 & 1.87 & .88 & \multirow{2}{*}{584} & \multirow{2}{*}{-1.721} & 006 \\
\hline & Female & 253 & 1.99 & .86 & & & .000 \\
\hline & Male & 333 & 2.22 & .92 & & & \\
\hline School management anxiety & Female & 253 & 2.20 & .86 & 584 & .276 & .783 \\
\hline & Female & 253 & 1.95 & .58 & & & \\
\hline A & Male & 333 & 3.39 & .63 & 504 & $2022 *$ & 026 \\
\hline Academie Sent-EIncacy sedie (10tal) & Female & 253 & 3.51 & .63 & 504 & $-2.250^{\circ}$ & .020 \\
\hline Soniol atatuc 0 & Male & 333 & 3.35 & .67 & 584 & 723 & 170 \\
\hline Soctal status & Female & 253 & 3.39 & .70 & 304 &.- .125 & $.4 / 0$ \\
\hline Connitive moliontions & Male & 333 & 3.44 & .66 & 584 & $2106 *$ & 000 \\
\hline 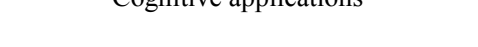 & Female & 253 & 3.61 & .66 & 504 & -5.100 & .002 \\
\hline Technicol ckills & Male & 333 & 3.30 & .79 & 584 & 733 & 464 \\
\hline 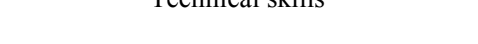 & Female & 253 & 3.35 & .87 & 304 & -.153 & .404 \\
\hline
\end{tabular}

(*) $\mathrm{p}<.05$ 
Table 4. ANOVA Results of Vocational Anxiety and Academic Self-Efficacy Scale scores according to grade level

\begin{tabular}{|c|c|c|c|c|c|c|c|c|}
\hline Scales and Subscales & Grade & $\mathrm{N}$ & Mean & SD & $\mathrm{df}$ & $\mathrm{F}$ & $\mathrm{p}$ & Post-Hoc \\
\hline \multirow{4}{*}{ Vocational Anxiety Scale (Total) } & $1^{\text {st }}$ & 162 & 1.84 & .55 & \multirow{4}{*}{$\begin{array}{c}3 \\
582\end{array}$} & \multirow{4}{*}{$3.15^{*}$} & \multirow{4}{*}{.025} & \multirow{4}{*}{$2>1,4$} \\
\hline & $2^{\text {nd }}$ & 146 & 2.02 & .61 & & & & \\
\hline & $3^{\text {rd }}$ & 145 & 1.90 & .65 & & & & \\
\hline & $4^{\text {th }}$ & 133 & 1.83 & .55 & & & & \\
\hline \multirow{4}{*}{ Job oriented anxiety } & $1^{\text {st }}$ & 162 & 1.53 & .58 & \multirow{4}{*}{$\begin{array}{c}3 \\
582\end{array}$} & \multirow{4}{*}{$3.29 *$} & \multirow{4}{*}{.020} & \multirow{4}{*}{$2>1$} \\
\hline & $2^{\text {nd }}$ & 146 & 1.75 & .66 & & & & \\
\hline & $3^{\text {rd }}$ & 145 & 1.64 & .69 & & & & \\
\hline & $4^{\text {th }}$ & 133 & 1.58 & .59 & & & & \\
\hline \multirow{4}{*}{ Socio-economic anxiety } & $1^{\text {st }}$ & 162 & 2.51 & .90 & \multirow{4}{*}{$\begin{array}{c}3 \\
582\end{array}$} & \multirow{4}{*}{$4.80^{*}$} & \multirow{4}{*}{.003} & \multirow{4}{*}{$\begin{array}{l}1>4 \\
2>4\end{array}$} \\
\hline & $2^{\text {nd }}$ & 146 & 2.57 & .91 & & & & \\
\hline & $3^{\text {rd }}$ & 145 & 2.37 & .99 & & & & \\
\hline & $4^{\text {th }}$ & 133 & 2.18 & .89 & & & & \\
\hline \multirow{4}{*}{ Interaction with students anxiety } & $1^{\text {st }}$ & 162 & 1.58 & .59 & \multirow{4}{*}{$\begin{array}{c}3 \\
316.04\end{array}$} & \multirow{4}{*}{$3.20^{*}$} & & \\
\hline & $2^{\text {nd }}$ & 146 & 1.83 & .81 & & & & \\
\hline & $3^{\text {rd }}$ & 145 & 1.68 & .75 & & & .024 & $2>1$ \\
\hline & $4^{\text {th }}$ & 133 & 1.65 & .68 & & & & \\
\hline & $1^{\text {st }}$ & 162 & 1.46 & .55 & & & & \\
\hline Collopouse and studente' narents anviety & $2^{\text {nd }}$ & 146 & 1.73 & .73 & 3 & $618 *$ & 000 & $2>14$ \\
\hline Colleagues and students parents anxiety & $3^{\text {rd }}$ & 145 & 1.72 & .76 & 314.84 & $0.18^{*}$ & .000 & $2>1,4$ \\
\hline & $4^{\text {th }}$ & 133 & 1.58 & .65 & & & & \\
\hline & $1^{\text {st }}$ & 162 & 1.74 & .89 & & & & \\
\hline & $2^{\text {nd }}$ & 146 & 1.86 & .87 & 3 & 130 & 272 & \\
\hline Individual selt-development anxiety & $3^{\text {rd }}$ & 145 & 1.72 & .92 & 582 & 1.30 & .272 & - \\
\hline & $4^{\text {th }}$ & 133 & 1.66 & .84 & & & & \\
\hline & $1^{\text {st }}$ & 162 & 2.59 & 1.10 & & & & \\
\hline & $2^{\text {nd }}$ & 146 & 2.77 & 1.12 & 3 & & & \\
\hline Occupational exam anxiety & $3^{\text {rd }}$ & 145 & 2.68 & 1.14 & 582 & 1.47 & .221 & - \\
\hline & $4^{\text {th }}$ & 133 & 2.85 & 1.08 & & & & \\
\hline & $1^{\text {st }}$ & 162 & 1.91 & .87 & & & & \\
\hline & $2^{\text {nd }}$ & 146 & 2.01 & .85 & 3 & 84 & 473 & \\
\hline Adaptation anxiety & $3^{\text {rd }}$ & 145 & 1.90 & .89 & 582 & .84 & .473 & - \\
\hline & $4^{\text {th }}$ & 133 & 1.85 & .88 & & & & \\
\hline & $1^{\text {st }}$ & 162 & 2.17 & .84 & & & & \\
\hline & $2^{\text {nd }}$ & 146 & 2.34 & .94 & 3 & & & \\
\hline School management anxiety & $3^{\text {rd }}$ & 145 & 2.18 & .91 & 582 & 1.38 & .248 & - \\
\hline & $4^{\text {th }}$ & 133 & 2.15 & .88 & & & & \\
\hline & $1^{\text {st }}$ & 162 & 3.42 & .59 & & & & \\
\hline Acodomic Self Efficony Scolo (Total) & $2^{\text {nd }}$ & 146 & 3.40 & .59 & 3 & 123 & 200 & \\
\hline Academic Selt-Efficacy scale (Total) & $3^{\text {rd }}$ & 145 & 3.44 & .69 & 582 & 1.23 & .300 & - \\
\hline & $4^{\text {th }}$ & 133 & 3.53 & .66 & & & & \\
\hline & $1^{\text {st }}$ & 162 & 3.35 & .64 & & & & \\
\hline & $2^{\text {nd }}$ & 146 & 3.34 & .64 & 3 & & & \\
\hline Socral status & $3^{\text {rd }}$ & 145 & 3.36 & .71 & 582 & .55 & 646 & - \\
\hline & $4^{\text {th }}$ & 133 & 3.43 & .73 & & & & \\
\hline & $1^{\text {st }}$ & 162 & 3.50 & .61 & & & & \\
\hline & $2^{\text {nd }}$ & 146 & 3.47 & .62 & 3 & 76 & 516 & \\
\hline Cognitive applications & $3^{\text {rd }}$ & 145 & 3.50 & .74 & 582 & .76 & .516 & - \\
\hline & $4^{\text {th }}$ & 133 & 3.59 & .70 & & & & \\
\hline & $1^{\text {st }}$ & 162 & 3.19 & .81 & & & & \\
\hline Tophnicolskillc & $2^{\text {nd }}$ & 146 & 3.21 & .79 & 3 & $5.50 *$ & 001 & $1>12$ \\
\hline Technical skills & $3^{\text {rd }}$ & 145 & 3.39 & .84 & 582 & $5.59^{*}$ & .001 & $4>1,2$ \\
\hline & $4^{\text {th }}$ & 133 & 3.53 & .82 & & & & \\
\hline
\end{tabular}

(*) $\mathrm{p}<.05$ 
According to the results of Levene's Test in Table 4, there is no homogenous variances in Vocational Anxiety Scale in sub-scales "Interaction with students anxiety" $(p=.003)$ and "colleagues and students' parents anxiety" $(p=.001)$. In terms of class varieties, the score differences between groups in the total scores of Occupational Anxiety Scale are significant $[F$ $(3,582)=3.145, p=.025]$. According to Tukey test results, the occupational anxiety scores of the second graders are higher than the scores of the first and fourth graders $(p<.05)$. In "job-oriented anxiety" sub-scale of Occupational Anxiety Scale, the occupational anxiety scores of the second graders are significantly higher than the anxiety scores of the first graders; and in "economic/social anxiety" sub-scale, the scores of the second and first graders are significantly higher than the scores of the fourth graders. According to Welch test results; in "interaction with students anxiety" sub-scale, the anxiety scores of the second graders are significantly higher than the scores of the first graders; and in "colleagues and students' parents anxiety" sub-scale, the anxiety scores of the second graders are higher than the scores of the first and fourth graders $(p<.05)$. There is no significant difference between the groups in the total scores of Academic Self-Efficacy Scale $[F(3,582)=1.225, p=.300]$. However, the academic self-efficacy scores of the fourth graders are significantly higher than the scores of the first and second graders in "Technical skills" sub-scale of Academic Self-Efficacy Scale ( $\mathrm{p}<.05)$.

Table 5. ANOVA results of Vocational Anxiety and Academic Self-Efficacy Scale scores according to participation in social activities

\begin{tabular}{|c|c|c|c|c|c|c|c|c|}
\hline Scales and Subscales & Activity & $\mathrm{N}$ & Mean & SD & $\mathrm{df}$ & $\mathrm{F}$ & $\mathrm{p}$ & Post-Hoc \\
\hline \multirow{3}{*}{ Vocational Anxiety Scale (Total) } & Yes & 321 & 1.87 & .58 & \multirow{3}{*}{$\begin{array}{c}2 \\
583\end{array}$} & \multirow{3}{*}{2.06} & \multirow{3}{*}{.128} & \multirow{3}{*}{ - } \\
\hline & Smt. & 210 & 1.90 & .60 & & & & \\
\hline & No & 55 & 2.05 & .66 & & & & \\
\hline \multirow{3}{*}{ Job oriented anxiety } & Yes & 321 & 1.61 & .64 & \multirow{3}{*}{$\begin{array}{c}2 \\
583\end{array}$} & \multirow{3}{*}{1.74} & \multirow{3}{*}{.176} & \multirow{3}{*}{ - } \\
\hline & Smt. & 210 & 1.61 & .62 & & & & \\
\hline & No & 55 & 1.78 & .67 & & & & \\
\hline \multirow{3}{*}{ Socio-economic anxiety } & Yes & 321 & 2.35 & .90 & \multirow{3}{*}{$\begin{array}{c}2 \\
583\end{array}$} & \multirow{3}{*}{$3.08 *$} & \multirow{3}{*}{.047} & \multirow{3}{*}{ No $>$ Yes } \\
\hline & Smt. & 210 & 2.44 & .94 & & & & \\
\hline & No & 55 & 2.69 & 1.04 & & & & \\
\hline \multirow{3}{*}{ Interaction with student anxiety } & Yes & 321 & 1.68 & .74 & \multirow{3}{*}{$\begin{array}{c}2 \\
583\end{array}$} & \multirow{3}{*}{.53} & \multirow{3}{*}{.591} & \multirow{3}{*}{ - } \\
\hline & Smt. & 210 & 1.66 & .67 & & & & \\
\hline & No & 55 & 1.77 & .73 & & & & \\
\hline \multirow{3}{*}{ Colleagues and students' parents anxiety } & Yes & 321 & 1.59 & .65 & \multirow{3}{*}{$\begin{array}{c}2 \\
583\end{array}$} & \multirow{3}{*}{1.22} & \multirow{3}{*}{.295} & \multirow{3}{*}{ - } \\
\hline & Smt. & 210 & 1.63 & .69 & & & & \\
\hline & No & 55 & 1.75 & .79 & & & & \\
\hline & Yes & 321 & 1.73 & .87 & & & & \\
\hline Individual self-development anxiety & Smt. & 210 & 1.76 & .90 & $\begin{array}{c}2 \\
583\end{array}$ & .18 & .834 & - \\
\hline & No & 55 & 1.79 & .89 & & & & \\
\hline & Yes & 321 & 2.67 & 1.10 & & & & \\
\hline Occupational exam anxiety & Smt. & 210 & 2.71 & 1.10 & $\begin{array}{c}2 \\
583\end{array}$ & 2.36 & .096 & - \\
\hline & No & 55 & 3.02 & 1.20 & & & & \\
\hline & Yes & 321 & 1.90 & .83 & & & & \\
\hline Adaptation anxiety & Smt. & 210 & 1.90 & .89 & $\begin{array}{c}2 \\
141.43\end{array}$ & $\begin{array}{l}\text { Welch } \\
1.06\end{array}$ & .351 & - \\
\hline & No & 55 & 2.12 & 1.06 & & & & \\
\hline & Yes & 321 & 2.16 & .89 & & & & \\
\hline School management anxiety & Smt. & 210 & 2.29 & .91 & $\begin{array}{c}2 \\
583\end{array}$ & 1.25 & .287 & - \\
\hline & No & 55 & 2.18 & .84 & & & & \\
\hline & Yes & 321 & 3.50 & .64 & & & & \\
\hline Academic Self-Efficacy Scale (Total) & Smt. & 210 & 3.40 & .60 & $\begin{array}{c}2 \\
583\end{array}$ & 2.84 & .059 & - \\
\hline & No & 55 & 3.31 & .65 & & & & \\
\hline & Yes & 321 & 3.48 & .67 & & & & \\
\hline Social status & Smt. & 210 & 3.25 & .66 & $\begin{array}{c}2 \\
583\end{array}$ & $9.23 *$ & .000 & Yes $>$ Smt, No \\
\hline & No & 55 & 3.20 & .71 & & & & \\
\hline & Yes & 321 & 3.53 & .68 & & & & \\
\hline Cognitive applications & Smt. & 210 & 3.51 & .64 & $\begin{array}{c}2 \\
583\end{array}$ & .63 & .535 & - \\
\hline & No & 55 & 3.42 & .69 & & & & \\
\hline & Yes & 321 & 3.41 & .83 & & & & \\
\hline Technical skills & Smt. & 210 & 3.25 & .81 & $\begin{array}{c}2 \\
583\end{array}$ & $4.91 *$ & .008 & Yes $>$ No \\
\hline & No & 55 & 3.09 & .81 & & & & \\
\hline
\end{tabular}

(*) $\mathrm{p}<.05$ 
According to the results of Levene's test in Table 5, the variances are not homogenous in "Adaptation anxiety" sub-scale $(p=0.009)$. The total scores of Vocational Anxiety Scale show no significant difference among the groups in terms of the participation in social, cultural, art and sportive activities $[F(2,583)=2.06 ; p=.128]$. However, the results of Tukey test show that in "economic/social anxiety" sub-scale of Occupational Anxiety Scale, the anxiety levels of those who do not participate in social activities are significantly higher than those who participate in social activities $(p<.05)$. There is no significant difference between the groups in the total scores of Academic Self-Efficacy Scale $[F(2,583)=2.84 ; p=.059]$. However, according to "social status" sub-scale of Academic Self-Efficacy Scale, the academic self-efficacy of those who participate in social activities are significantly higher than those who never or sometimes participate in the activities; and in "technical skills" sub-scale, those who participate in social activities have significantly higher level of academic self-efficacy than those who do not participate $(p<.05)$.

Table 6. ANOVA results according to subjective academic achievement variable of Vocational Anxiety and Academic Self-Efficacy Scale Scores

\begin{tabular}{|c|c|c|c|c|c|c|c|c|}
\hline Scales and Subscales & $\begin{array}{c}\text { Academic } \\
\text { achievement }\end{array}$ & $\mathrm{N}$ & Mean & $\mathrm{SD}$ & df & $\mathrm{F}$ & $\mathrm{p}$ & Post-Hoc \\
\hline \multirow{3}{*}{ Vocational Anxiety Scale (Total) } & Poor & 33 & 2.20 & .67 & \multirow{3}{*}{$\begin{array}{c}2 \\
583\end{array}$} & \multirow{3}{*}{$5.17 *$} & \multirow{3}{*}{.006} & \multirow{3}{*}{$\begin{array}{l}\text { Poor }>\text { Mid. \& } \\
\text { Good }\end{array}$} \\
\hline & Middle & 323 & 1.90 & .59 & & & & \\
\hline & Good & 230 & 1.84 & .59 & & & & \\
\hline \multirow{3}{*}{ Job oriented anxiety } & Poor & 33 & 1.95 & .73 & \multirow{3}{*}{$\begin{array}{c}2 \\
583\end{array}$} & \multirow{3}{*}{$5.15^{*}$} & \multirow{3}{*}{.006} & \multirow{3}{*}{$\begin{array}{l}\text { Poor }>\text { Mid. \& } \\
\text { Good }\end{array}$} \\
\hline & Middle & 323 & 1.62 & .61 & & & & \\
\hline & Good & 230 & 1.58 & .64 & & & & \\
\hline \multirow{3}{*}{ Socio-economic anxiety } & Poor & 33 & 2.65 & 1.01 & \multirow{3}{*}{$\begin{array}{c}2 \\
583\end{array}$} & \multirow{3}{*}{1.21} & \multirow{3}{*}{.298} & \multirow{3}{*}{-} \\
\hline & Middle & 323 & 2.42 & .90 & & & & \\
\hline & Good & 230 & 2.38 & .97 & & & & \\
\hline \multirow{3}{*}{ Interaction with students anxiety } & Poor & 33 & 2.11 & .90 & \multirow{3}{*}{$\begin{array}{c}2 \\
583\end{array}$} & \multirow{3}{*}{$6.79 *$} & \multirow{3}{*}{.001} & \multirow{3}{*}{$\begin{array}{c}\text { Poor }>\text { Mid.\& } \\
\text { Good }\end{array}$} \\
\hline & Middle & 323 & 1.68 & .69 & & & & \\
\hline & Good & 230 & 1.62 & .70 & & & & \\
\hline \multirow{3}{*}{ Colleagues and students' parents anxiety } & Poor & 33 & 1.89 & .71 & \multirow{3}{*}{$\begin{array}{c}2 \\
583\end{array}$} & \multirow{3}{*}{2.91} & \multirow{3}{*}{.055} & \multirow{3}{*}{-} \\
\hline & Middle & 323 & 1.61 & .68 & & & & \\
\hline & Good & 230 & 1.59 & .67 & & & & \\
\hline & Poor & 33 & 2.14 & .86 & & & & \\
\hline Individual self-development anxiety & Middle & 323 & 1.78 & .90 & $\begin{array}{c}2 \\
583\end{array}$ & $5.28 *$ & .005 & Poor $>$ Good \\
\hline & Good & 230 & 1.64 & .84 & & & & \\
\hline & Poor & 33 & 3.03 & 1.23 & & & & \\
\hline Occupational exam anxiety & Middle & 323 & 2.78 & 1.06 & $\begin{array}{c}2 \\
583\end{array}$ & $3.63 *$ & .027 & Poor $>$ Good \\
\hline & Good & 230 & 2.58 & 1.14 & & & & \\
\hline & Poor & 33 & 2.20 & 1.13 & & & & \\
\hline Adaptation anxiety & Middle & 323 & 1.88 & .84 & $\begin{array}{c}2 \\
583\end{array}$ & 2.01 & .134 & - \\
\hline & Good & 230 & 1.93 & .87 & & & & \\
\hline & Poor & 33 & 2.21 & .93 & & & & \\
\hline School management anxiety & Middle & 323 & 2.23 & .88 & $\begin{array}{c}2 \\
583\end{array}$ & .21 & .808 & - \\
\hline & Good & 230 & 2.18 & .91 & & & & \\
\hline & Poor & 33 & 3.16 & .53 & & & & \\
\hline Academic Self-Efficacy Scale (Total) & Middle & 323 & 3.36 & .60 & $\begin{array}{c}2 \\
583\end{array}$ & $13.70^{*}$ & .000 & Good $>$ Mid. \& \\
\hline & Good & 230 & 3.60 & .65 & & & & \\
\hline & Poor & 33 & 3.16 & .63 & & & & \\
\hline Social status & Middle & 323 & 3.31 & .66 & $\begin{array}{c}2 \\
583\end{array}$ & $6.67^{*}$ & .001 & Good $>$ Mid. \& \\
\hline & Good & 230 & 3.49 & .70 & & & & \\
\hline & Poor & 33 & 3.18 & .54 & & & & \\
\hline Cognitive applications & Middle & 323 & 3.42 & .64 & $\begin{array}{c}2 \\
583\end{array}$ & $15.95^{*}$ & .000 & $\begin{array}{l}\text { Good }>\text { Mid. \& } \\
\text { Poor }\end{array}$ \\
\hline & Good & 230 & 3.69 & .68 & & & & \\
\hline & Poor & 33 & 3.08 & .83 & & & & \\
\hline Technical skills & Middle & 323 & 3.24 & .80 & $\begin{array}{c}2 \\
583\end{array}$ & $7.31 *$ & .001 & Good $>$ Mid. \& \\
\hline & Good & 230 & 3.48 & .84 & & & & \\
\hline
\end{tabular}

(*) $\mathrm{p}<.05$ 
According to the results of Levene's test in Table 6, the variances are homogenous. The results of the variance analysis show that the score differences between groups in the total scores of Occupational Anxiety Scale are statistically significant $[F(2,583)=5.168 ; p=.006]$. According to Tukey test results, the occupational anxiety level of those who consider their academic success as "poor" $(M=2.20 ; S D=.67)$ are significantly higher than those who consider their academic success as "middle" and "good" $(p<.05)$. The difference between the groups for the total scores of Academic Self-Efficacy scores are also significant $[F(2,583)=13.666 ; p=.000]$. According to Tukey's test results, those who consider their academic success as "good" have higher scores than those who consider their academic success as "middle" or "poor" $(p<.05)$.

Table 7 represents the results of correlation analysis for total and sub-scale scores of Occupational Anxiety Scale and Academic Self-Efficacy Scale. The results reveal a negative and statistically significant correlation between the total scores of Occupational Anxiety Scale and Academic Self-Efficacy Scale $(r=-.33 ; p<.01)$. Similarly, there is a negative and significant correlation between the sub-scales of both scales. In other words; as the occupational anxiety level of the candidates increases, their perception of academic self-efficacy significantly decreases.

\section{Discussion}

This study was conducted to determine the levels of occupational anxiety and academic self-efficacy of physical education teacher candidates and to examine them in terms of gender, class level, participation in sports and social activities and subjective perception of academic achievement. According to the results of the analysis conducted for the first research question "Research question 1. What is the occupational anxiety and academic self-efficacy level of the participants?", it is indicated that the highest level of occupational anxiety experienced by the participants is for "occupational exam anxiety" (Table 2). Physical education teachers, as well as branch teacher candidates in other fields, have a similar appointment-oriented anxiety. For instance, Çelikten et.al. [51] found similar results in their study conducted on pre-service teachers. The study, conducted by Taşğın [8] on the occupational anxiety levels of physical education teacher candidates, revealed that they were worried only before they were appointed and they had concerns about whether they would be successful in the profession. Another study conducted to determine the occupational anxiety levels of form teachers found that form teacher candidates had low level of occupational anxiety [41]. It is possible that physical education teacher candidates have occupational exam anxiety only because it is not certain whether they will be successful at KPSS (Public Servant Selection Test). However, as a result of the training and education that the participants received in the universities, their occupational attitudes, self-efficacy perceptions, academic motivations and academic-self efficacy perceptions might have an impact on their academic achievements and the high level of appointment-oriented anxiety. The previous studies showed a negative correlation between self-efficacy belief and occupational anxiety [16, 20], and a positive correlation between self-efficacy and occupational attitudes [16]. On the other hand; a study conducted with pre-service teachers of education faculty indicated that according to employment variances, the anxiety levels of those who were pessimistic were significantly higher than those who were optimistic [21].

Table 7. The results of correlation analysis for total and sub-scales of Occupational Anxiety Scale (OAS) and the Academic Self-Efficacy Scale (ASES)

\begin{tabular}{|c|c|c|c|c|}
\hline Variables & ASES (Total) & Social status & Cognitive applications & Technical skills \\
\hline Vocational Anxiety Scale (Total) & $-.334^{* *}$ & $-.260^{* *}$ & $-.341^{* *}$ & $-.269^{* *}$ \\
\hline Job oriented & $-.337^{* *}$ & $-.254^{* *}$ & $-.353^{* *}$ & $-.250^{* *}$ \\
\hline Socio-economic & $-.190^{* *}$ & $-.147^{* *}$ & $-.178^{* *}$ & $-.214^{* *}$ \\
\hline Interaction with students & $-.275^{* *}$ & $-.221^{* *}$ & $-.281^{* *}$ & $-.205^{* *}$ \\
\hline Colleagues and students' parents & $-.295^{* *}$ & $-.226^{* *}$ & $-.309^{* *}$ & $-.209^{* *}$ \\
\hline Individual self-development & $-.276^{* *}$ & $-.239^{* *}$ & $-.273^{* *}$ & $-.201^{* *}$ \\
\hline Occupational exam & $-.178^{* *}$ & $-.133^{* *}$ & $-.187^{* *}$ & $-.133^{* *}$ \\
\hline Adaptation & $-.166^{* *}$ & $-.135^{* *}$ & $-.161^{* *}$ & $-.151^{* *}$ \\
\hline School management & $-.201^{* *}$ & $-.145^{* *}$ & $-.209^{* *}$ & $-.165^{* *}$ \\
\hline \multicolumn{2}{|l}{$*$ Correlation is significant at the .01 level (2-tailed). } \\
\hline
\end{tabular}


The analysis of participants' academic self-efficacy perceptions concludes that PE teacher candidates have the lowest score for "technical skills" sub-scale (Table 2). Another study conducted with pre-service teachers of education faculty showed that there was no significant difference between the groups according to the comparison between the academic self-efficacy perception level of PE teacher candidates and other field candidates (Social Sciences, Physics, Maths and Foreign Language) [52]. According to Bloom's Mastery Learning Model [53], a teacher candidate is expected to have cognitive, emotional and practical knowledge and skills. The result of this study state that PE teacher candidates consider themselves efficient in "cognitive" field yet inefficient in "technical skills/practices". The reason for having a low score in "technical skills" sub-scale can be explained through the fact that technical practices - theoretical knowledge - can't be transferred enough to practical knowledge in the education process. Another study conducted with form teacher candidates revealed certain findings that technology played an important role in the future of teaching profession and teachers should have been trained to have advanced technical skills [14].

"Research question 2. Are the occupational anxiety and academic self-efficacy levels of the participants varied by gender, class level, participation in social activities and the variables of the evaluation of subjective academic achievement?"

The comparison between occupational anxiety levels of the participants by gender variance shows that the scores of female candidates are significantly higher than the scores of male candidates in the total scores and "economic/social anxiety" and "appointment-oriented anxiety" sub-scales of Occupational Anxiety Scale (Table 3). The studies conducted with pre-service and in-service teachers [22] also indicated that occupational anxiety levels of female participants were higher than male participants, while some other studies found that gender variances were ineffective [19-21,42]. The fact that female participants have higher levels of appointment and they have economic/social anxieties can be interpreted as the results of the social, cultural and economic environments where they live. Similarly, Akgün et.al [22] suggested that women's higher level of occupational anxiety could have been affected by social values, socio-economic and cultural characteristics of their families, gender inequality and the development level of the region.

Gender-oriented comparison of academic self-efficacy perceptions of the participants reveals that the academic self-efficacy scores of the male and female participants differ, and that females' scores in the total and "cognitive applications" sub-scale of Academic Self-Efficacy Scale are significantly higher than the score of male participants (Table 3). On the other hand; the study conducted by Tabancalı and Kazım [52] with the students from different departments of education faculty, the study conducted by
Akbaş and Çekilelli [43] on physical science teaching of pre-service form teachers, and the study conducted by Sandıkçı and Öncü [54] on the occupational self-efficacy perceptions of pre-service PE teachers showed that there was no difference by gender. However, many studies on academic success found that women had higher academic success than men $[55,56]$ as there was a positive correlation between academic success and academic self-efficacy [47-49, 57]. In our study, the differences in the academic self-efficacy perceptions of PE teacher candidates may be due to women's desire and needs to participate in the work force and obtain economic independence and participate in social life and to be liberated when social and cultural factors are taken into consideration. For this reason, female teacher candidates may feel more successful than men in their academic life.

According to ANOVA test results to compare the occupational anxiety levels of the participants by grade level variance; the occupational anxiety levels of second graders are significantly higher than the levels of first and fourth graders in the total scores of Occupational Anxiety Scale. Although there is no significant difference between classes in terms of "appointment-oriented anxiety" sub-scale of Occupation Anxiety Scale, it is interesting that the severity of occupational anxiety is constantly increasing (Table 4). In analogy to our study results, another study on the occupational anxiety of pre-service form teacher candidates showed that occupational anxiety differed depending on grade level variance [9]. Nonetheless, some studies concluded that occupational anxieties did not differentiate in terms of grade level variance $[17,18]$. In our study, it can be interpreted that PE teacher candidates experience a continuous occupational anxiety starting from the first years in the profession, and since occupational anxiety level differ between the grades, it reaches up to the optimum level in $2^{\text {nd }}$ grade and "appointment-oriented anxiety" doesn't differ between the grades. PE teacher candidates' experience of a lasting occupational anxiety might negatively affect their attitudes towards the teaching profession as there is a middle-level negative correlation between the attitudes towards the profession and occupational anxiety [17].

Although the academic self-efficacies of the participants do not show a continuous increase in terms of grade level variance, the $4^{\text {th }}$ graders differ from $1^{\text {st }}$ and $2^{\text {nd }}$ graders only in "technical skills" sub-scale (Table 4). In the previous studies on academic self-efficacy, a significant difference depending on the grade levels was also observed [45-47]. It can be interpreted in this ongoing study that the continuous increase in the technical skills of the candidates depending on their grade levels and the significant differentiation in the final grade are related to training and education that the candidates receive. In other words, PE teaching departments gradually increase their efficiency in teaching PE teacher candidates so that they acquire better technical skills every year.

For the comparison between the scores that participants get from the Occupational Anxiety Scale, the sub-scale and 
the variables of "sports" and "participation in social and cultural activities", the results of Table 5 reveal that only in "economic/social anxiety" sub-scale, the anxiety scores of those who do not participate in activities are significantly higher than the participants. Despite our findings, the study conducted by Kafkas et.al [20] with PE teacher candidates reported that active participation in sports had no impact on occupational anxiety. The literature review indicates that the participation in social and cultural activities are effective in mitigating anxiety and coping with stress $[58,59]$. In our study, it can be stated that the findings suggesting that the anxiety level of PE teacher candidates, who do not participate in sport, social and cultural activities, is significantly higher than those who participate in the activities are compatible with the findings of literature review; and this difference can be explained by the fact that the socialization skills of those who do not participate in social activities are less developed as they lack social interaction. The analysis of the academic self-efficacy of the participants with regard to the variable of "participation in sports", "social and cultural activities" showed that those who participate in the activities received significantly higher scores in "social status" and "technical skills" sub-scales than those who did not participate (Table 5). Individuals can gain a lot of knowledge and skills through participation in sports, social and cultural activities, and they can also be influential in acquiring a social role. Participation in such activities is also thought to be effective in obtaining some technical skills; which might explain the significant difference between the groups.

In terms of subjective academic achievement variable, the anxiety levels of those, who consider their anxiety levels as "poor" in the total score and "job-oriented anxiety", "interaction with students", "individual self-development" and "appointment-oriented anxiety" sub-scales of Occupational Anxiety Scale, are significantly higher than those who consider their anxiety levels as "good" (Table 6).

The previous studies already showed that there was a mid-level correlation between occupational anxiety and self-efficacy [20], and a negative correlation between the occupational self-efficacy perception and occupational anxiety levels of the form teacher candidates $[9,16]$. Sandıkçı and Öncü [54] also compared the occupational competency and the attitudes of PE and other field teacher candidates, and revealed that those who had higher academic achievements had better perception of self-efficacy and competency than those who had lower academic achievement. Psychologically, people who have high anxiety levels develop low level of the competence perceptions $[2,23]$. In our study, those with low academic achievement have a higher vocational anxiety score. If the issue of appointment is resolved, or the academic achievement of PE teacher candidates is improved, then the candidates will have lower level of professional anxiety.

In terms of the total and the sub-scale scores of Academic Self-Efficacy Scale, the results indicated that PE teacher candidates, who subjectively evaluate their academic achievements as "good", have significantly higher scores than those who evaluate their academic achievements as "middle" or "poor". Academic self-efficacy is defined one's self-competency and self-belief in his/her successful accomplishment of academic tasks that are assigned to $\mathrm{him} / \mathrm{her}$ during education period [32]. The previous studies stated that individuals, who have higher levels of academic self-efficacy, show higher academic performance [47], and there is a positive correlation between self-efficacy perceptions and life-long learning motivations of teacher candidates [60], and between academic self-efficacy and academic motivation [61]. The result of another study conducted on the academic self-efficacy of teacher candidates concluded that those who had better academic achievements (81-90 points) significantly differed from those who had middle (71-80 points) or poor (61-70 points) achievements [42].

Research question 3. "Is there a correlation between the occupational anxiety levels and academic self-efficacy perceptions of the participants?"

The results of correlation analysis show that there is a negative and significant correlation between the scores of Occupational Anxiety Scale and Academic Self-Efficacy Scale (Table 7). In other words, an increase in the occupational anxiety scores of the participants may result in a decrease in their self-efficacy scores. The results of previous studies also indicated that those who had higher academic self-efficacy scores also had better academic achievements [47-49]. Another study conducted on teacher candidates reported that the academic self-efficacy perceptions of teacher candidates were negatively affected by occupational exam anxiety [42]. Considering the fact that mid-level anxiety can have a positive impact on performance, and low and severe anxiety can have a negative impact on individuals' performance [23], the results of our study show that there is a negative and significant correlation between occupational anxiety levels and academic self-efficacy perceptions of the participants; which can be interpreted that PE teacher candidates, who participate in our study, experience a high level of occupational anxiety. This result also shows that the high level of occupational anxiety can negatively impact the participants' academic self-efficacy and thus decrease their performance, and the achievement of general and specific teaching skills expected from teacher candidates.

\section{Conclusions}

The fact that PE teacher candidates experience higher level of appointment-oriented anxiety has a negative impact on their academic self-efficacy. The fact that candidates have been constantly anxious since the first day they started university also negatively affects their academic self-efficacy. Besides, the participants' low scores in 
"technical skill" sub-scale are regarded being due to the lack of practice and technology usage experience. It can be concluded that the participation in social, cultural and sports activities can create a positive impact on occupational anxiety and academic self-efficacy, and academic self-efficacy can help improve academic achievement. As a result, in order to decrease vocational anxiety levels of physical education teacher candidates, it is suggested to solve the problems of appointment-oriented anxiety and to take necessary precautions to increase academic achievement.

\section{REFERENCES}

[1] AnaBritannica Genel Kültür Ansiklopedisi. 13. Cilt, Istanbul: Anayayınc1lık A. S. ve Encylopaedia Anabritannica, INC., 1993.

[2] Cüceloğlu D. İnsan ve Davranışları: Psikolojinin Temel Kavramları. 6. Basım, İstanbul: Remzi Kitabevi, 1996.

[3] Bozdam A. (2008). Öğretmen Adaylarının Mesleki Kaygı Düzeylerinin Bazı Değişkenler Açısından İncelenmesi”, Yüksek Lisans Tezi, Konya: Selçuk Üniversitesi, Sağlık Bilimleri Enstitüsü.

[4] Morgan CT. Psikolojiye Giriş. Çev. Hüsnü Arıcı ve diğ., 11. Bask1, Ankara: METEKSAN, 1995.

[5] Freud S. Civilization, Religion and Society. Harmondsworth: Penguin, 1985.

[6] Fuller F. Concerns of teachers: A developmental conceptualization. American Education Research Journal, No. 6, 207-226, 1969.

[7] Fuller F. and Case C. Concerns of Teachers. A Manual for Teacher Educators: Increasing Teacher Satisfaction with Professional Preparation by Considering Teachers' Concerns when Planning Preservice and Inservice Education. Texas Univ., Austin. Research and Development Center for Teacher Education, Office of Education (DHEW), Washington, D.C., 1969.

[8] Taşğın Ö. Beden Eğitimi ve Spor Yüksekokulunda okuyan öğretmen adaylarının mesleki kaygı düzeylerinin bazı değişkenler açısından incelenmesi: Selçuk Üniversitesi Örneği. Kastamonu Eğitim Dergisi, 14(2), 679-686, 2006.

[9] Y1ldırım A. Investigation of the relationship between primary school teacher candidates' sense of self-efficacy and professional anxiety. Yüksek Lisans Tezi, Istanbul: Marmara Üniversitesi, Eğitim Bilimleri Enstitüsü, İlköğretim Anabilim Dal1, Tez No. 298589, 2011.

[10] Gordon EJ. Concerns of the Novice Physical Education Teacher. The Physical Educator, 73, 652-670, 2016.

[11] Atmaca H. Almanca, Fransızca ve İngilizce öğretmenliği bölümlerinde okuyan öğretmen adaylarının mesleki kaygıları. International Periodical for The Languages, Literature and History of Turkish or Turkic, 8 (10), 67-76, 2013.

[12] Altun E., Ateş A. The Problems and Future Concerns of
Computer and Instructional Technologies Preservice Teachers. Elementary Education Online, 7(3), 680-692, 2008.

[13] Cabi E.,Yalçınalp S. Öğretmen adaylarına yönelik mesleki kayg1 ölçeği (MKÖ): Geçerlik ve güvenirlik çalışması. Hacettepe Üniversitesi Eğitim Fakültesi Dergisi (H. U. Journal of Education), 44, 85-96, 2013.

[14] Belet-Boyacı ŞD., Küçükyılmaz EA. and Genç-Ersoy B. Future of Classroom Teaching According to the Pre Service Classroom Teachers. Journal of Education and Future, 9, 1-30, 2016.

[15] Gray L., Taie S. Public school teacher attrition and mobility in the first five years. Retrieved from U.S. Department of Education website. Retrieved December 10, 2016, from http://nces.ed.gov/pubs2015/2015337.pdf, 2015.

[16] Dadandı İ., Kalyon A., Yazıc1 H. Eğitim Fakültesinde Öğrenim Gören ve Pedagojik Formasyon Eğitimi Alan Öğretmen Adaylarının Öz-Yeterlik İnançları, Kaygı Düzeyleri ve Öğretmenlik Mesleğine Karşı Tutumları. Bayburt Eğitim Fakültesi Dergisi, 11(1), 253-269, 2016.

[17] Serin MK., Güneş AM., Değirmenci H. Sınıf Öğretmenliği Bölümü Öğrencilerinin Öğretmenlik Mesleğine Yönelik Tutumları İle Mesleğe Yönelik Kaygı Düzeyleri Arasındaki İlişki. Cumhuriyet International Journal of Education, 4(1), 21-34, 2015.

[18] Aydın A., Tekneci E. Zihin engelliler öğretmenliği öğrencilerinin öğretmenlik mesleğine yönelik tutumları ile kaygı düzeyleri. Pegem Eğitim ve Öğretim Dergisi, 3(2), 1-12, 2013.

[19] Dursun S., Karagün E. Öğretmen Adaylarının Mesleki Kayg1 Düzeylerinin İncelenmesi: Kocaeli Üniversitesi Beden Eğitimi ve Spor Yüksekokulu Son Sinıf Öğrencileri Üzerine Bir Araştırma. Kocaeli Üniversitesi Sosyal Bilimler Dergisi, 24, 93-112, 2012.

[20] Kafkas M E., Açak M., Çoban B., Karademir T. Beden Eğitimi Öğretmen Adaylarının Öz-Yeterlik Algıları İle Mesleki Kaygıları Arasındaki İlişki. İnönü Üniversitesi Eğitim Fakültesi Dergisi, 11(2), 93-111, 2010

[21] Doğan T., Çoban AE. The Investigation of The Relations Between Students' Attitude Toward Teaching Profession and Anxiety Level in Faculty of Education. Education and Science, 34(153), 157-168, 2009.

[22] Akgün A., Gönen S., Aydın M. The Investigation Of Anxiety Levels Of Primary School Science And Mathematics Teacher Students' According to Some Variables. Electronic Journal of Social Sciences, 6(20), 283-299, 2007.

[23] Elliot SN., Karatochwill TR., Littlefield-Cook J., Travers JF. Educational Psychology. 3th ed, New York: McGraw-Hill Companies, 1996.

[24] Aronson, E., Wilson, T. D., \& Akert, R. M. Social Psychology.7th ed., New York: Longman, 1997.

[25] Bandura A. Social foundations of thought and action: A social cognitive theory. Englewood Cliffs, NJ: Prentice Hall, 1986.

[26] Senemoğlu N. Gelişim, Öğrenme ve Öğretim: Kuramdan Uygulamaya. 2. Bask1, Ankara: Gazi Kitabevi, 2000.

[27] Schunk DH. Self-efficacy and academic motivation. Educational Psychologist, 26(3), 207-231. doi: 
10.1080/00461520.1991.9653133, 1991.

[28] Zimmerman BJ., Martinez-Pons M. Student differences in self-regulated learning: Relating grade, sex, and giftedness to self-efficacy and strategy use. Journal of Educational Psychology, 82, 51-59, 1990.

[29] Bandura A. Self-Efficacy: The Exercise of Control. New York: W.H. Freeman, 1997.

[30] Zimmerman BJ. Self-Efficacy: An Essential Motive to Learn. Contemporary Educational Psychology, 25, 82-91, 2000.

[31] Linnenbrink EA., Pintrich PR. The role of self-efficacy beliefs in student engagement and learning. Reading and Writing Quarterly, 19(2), 119-137. doi: 10.1080/10573560308223, 2003.

[32] Bong M. Academic Motivation in Self Efficacy, Task Value, Achievement Goal Orientations And Attributional Belief. Journal of Educational Research, 97(6), 287-297, 2004.

[33] Ekici G. Akademik öz-yeterlik ölçeği: Tükçe'ye uyarlama, geçerlik ve güvenirlik çalışması. Hacettepe Üniversitesi Eğitim Fakültesi Dergisi (H. U. Journal of Education), 43: 174-185, 2012.

[34] Schunk DH., Pajares F. The Development of Academic Self-Efficacy, In A. Wigfield \& J. S. Eccles (Eds.), Development of Achievement Motivation, 15-31, San Diego: Academic Press, 2002.

[35] Pajares F. Self-Efficacy Beliefs in Academic Settings. Review of Educational Research, 66(4), 543-578, 1996.

[36] Ünlü H., Sünbül AM., Aydos L. Beden Eğitimi Öğretmenleri Yeterlilik Ölçeği Geçerlilik ve Güvenirlik Çalışması. Ahi Evran Üniversitesi Eğitim Fakültesi Dergisi, 9(2), 25-23, 2008.

[37] Güçlü N. Sistem Yaklaşımı ve Eğitim Örgütleri: Öğretmenlik Mesleğine Giriş. Ed. Leyla Küçükahmet, Ankara: Nobel Yayın Dağıtım, 2002.

[38] Gökçe E. İlköğretim Sınıf Öğretmenlerinin Yeterlikleri. Çağdaş Eğitim Dergisi, 299, 36-48, 2003.

[39] Yılmaz M., Köseoğlu P., Gerçek C., Soran H. Öğretmen Öz Yeterlik İnancı. Bilim ve Aklın Aydınlığında Eğitim Dergisi. 58, 2004.

[40] Yılmaz G., Yilmaz B., Türk N. Beden Eğitimi ve Spor Öğretmenlerinin Mesleklerine İlişkin Öz Yeterlik Düzeylerinin İncelenmesi (Nevşehir İli Örneği). Selçuk Üniversitesi Beden Eğitimi ve Spor Bilim Dergisi, 1,2, 85-90, 2010.

[41] Yeşilyurt E. Academic Self-Efficacy Perceptions of Teacher Candidates. Mevlana International Journal of Education, 3(1), 93-103, http://mije.mevlana.edu.tr/, 2013.

[42] Yeşilyurt E. Academic Locus of Control, Tendencies towards Academic Dishonesty and Test Anxiety Levels as the Predictors of Academic Self-efficacy. Educational Sciences: Theory \& Practice, 14(5), 1945-1956, 2014.

[43] Akbaş A., Çelikelli Ö. The Investigation of the Preservice Elementary Teachers' Science Instruction Self-Efficacy Beliefs According to Their Gender, Type of Education, and Universities. Mersin University Journal of the Faculty of Education, 2(1), 98-110, 2006.
[44] Satıcı SA. Üniversite öğrencilerinin akademik öz-yeterliklerinin çeşitli değişkenler açısından incelenmesi / Investigation of academic self-efficacy of university students in terms of various variables. Yüksek Lisans Tezi, Eskişehir: Anadolu Üniversitesi, Eğitim Bilimleri Enstitüsü, 2013.

[45] Tunca N., Alkın-Şahin S. The Relationship Between Pre-Service Teachers' Metacognitive Learning Strategies and Academic Self-Efficacy. Anadolu Journal of Educational Sciences International, 4(1), 47-56, 2014.

[46] Bümen NT., Ercan-Özaydın T. Changes on Teacher Self-Efficacy and Attitudes Towards Teaching Profession From Candidacy to Induction. Education and Science, 38(169), 109-125, 2013.

[47] Chemers M., Hu L., Garcia B. Academic selfefficacy and first year college student performance and adjustment. Journal of Educational Psychology, 93(1), 55-64, 2001.

[48] Putwain D., Sander P., Larkin D. Academic self-efficacy in study-related skills and behaviours: Relations with learning-related emotions and academic success. British Journal of Educational Psychology, 83, 633-650, 2013.

[49] Catalina CC., Stanescu DF., Mohorea L. Academic self-efficacy, emotional intelligence and academic achievement of Romanian students: Results from an exploratory study. Journal of Educational Sciences \& Psychology, II(LXIV), 41-51, 2012.

[50] Owen S., Froman RD. Development of a college academic self-efficacy scale. Paper presented at the annual meeting of the national council on measurement in education, New Orleans. LA., 1988.

[51] Çelikten M., Şanal M., Yeni Y. Öğretmenlik Mesleği ve Özellikleri. Sosyal Bilimler Enstitüsü Dergisi, 19(2), 207-237, 2005.

[52] Tabancalı E., Çelik K. The relationship between academic self-efficacy and self-efficacy levels of teacher candidates. International Journal of Human Sciences, 10(1), 1167-1184, 2013.

[53] Bloom BS. İnsan Nitelikleri ve Okulda Öğrenme [Human Characteristics and School Learning]. Çev. Durmuş Ali Özçelik, 2. Baskı, Ankara: Pegem Akademi, 2012.

[54] Sandıkçı M., Öncü E. Determination and Comparison of Physical Education and the Other Pre-Service Teachers' Self-Efficacy Beliefs and Attitudes toward Teaching Profession. Pamukkale Journal of Sport Sciences, 4(1), 135-151, 2013.

[55] Bahar HH. An Evaluation of KPSS Scores According to Grade Point Avarege and Gender. Education and Science, 31(140), 68-74, 2006.

[56] Balkıs M., Duru E., Buluş M., Duru S. The Prevalence of Burnout among Prospective Teachers, It's Relation with Demographic Variables and Academic Achievement. Pamukkale Üniversitesi Eğitim Fakültesi Dergisi, 29(I),. 151-165, 2011.

[57] Alfaro EC., Umana-Taylor AJ., Gonzales-Backen MA., Ba'maca MY., Katharine H., Zeiders KH. Latino adolescents' academic success: The role of discrimination, academic motivation, and gender. Journal of Adolescence, 32, 941-962, 2009. 
[58] Okutan M., Tengilimoğlu D. İş Ortamında Stes ve Stresle Başa Çıkma Yöntemleri: Bir Alan Uygulaması. G.Ü. İktisadi ve İdari Bilimler Dergisi, 3, 15-42, 2002.

[59] Aydın B., İmamoğlu S. Stresle Başaçikma Becerisi Geliştirmeye Yönelik Grup Çalişmasi. M.Ü. Atatürk Eğitim Fakültesi Eğitim Bilimleri Dergisi, 14, 41-52, 2001.

[60] Akyol B. Teacher Self-Efficacy Perceptions, Learning
Oriented Motivation, Lifelong Learning Tendencies of Candidate Teachers: A Modeling Study. Eurasian Journal of Educational Research, 65, 19-34, 2016.

[61] Avara K. Ortaöğretim Öğrencilerinde Akademik Güdülenmenin Yordayıcısı Olarak Akademik Öz-Yeterlik, Kariyer Kararı Yetkinlik Beklentisi ve Okul Tükenmişliği. Yüksek Lisans Tezi, Konya: Mevlana Üniversitesi, Sosyal Bilimler Enstitüsü, 2015. 